\title{
Drying and storage of macaúba fruit: chemical and oxidative stability
}

\section{Secagem e armazenamento de frutos de macaúba: estabilidade química e oxidativa}

\author{
Vanessa Mandú da Silva ${ }^{1}$; Rita de Cássia Avellaneda Guimarães ${ }^{2}$; \\ Raquel Pires Campos ${ }^{2}$; Aurélio Vinicius Borsato ${ }^{3}$; Priscila Aiko Hiane ${ }^{2}$; \\ Juliana Rodrigues Donadon ${ }^{2 *}$
}

Highlights:

Post-harvest of bocaiuva fruits (Acrocomia sp); drying and storage.

Physical analysis of fruit and pulp. Chemical analysis of pulp and almond;

Extraction and quality of almond pulp and oil.

\begin{abstract}
The objective of this study was to evaluate the chemical and oxidative stability of dried macaúba (Acrocomia totai) fruit in different air conditions and stored for up to 120 days. The macaúba fruits were collected, sanitized, dried at the temperatures of $40,50,60$ and $70{ }^{\circ} \mathrm{C}$ and stored in raffia bags at room temperature. Drying at higher temperatures resulted in pulps with a darker and orangish color and pulp oil with lower titratable acidity contents and acidity indices. Throughout storage, there was an increase in the acidity index of pulp oil and a reduction in the ascorbic acid and carotenoid contents in the pulp. Drying and storage reduced the ascorbic acid and carotenoid contents of the pulp. Drying at lower temperatures results in pulps with a higher free-radical sequestering ability. Pulp oil quality was compromised by drying and storage time. Newly harvested macaúba fruits can be dried at $40,50,60$ or $70{ }^{\circ} \mathrm{C}$ and stored for up to 120 days without compromising nut oil quality.
\end{abstract}

Key words: Acrocomia totai. Antioxidant. Temperature. Dehydration. Oil.

\section{Resumo}

Este trabalho teve por objetivo avaliar a estabilidade química e oxidativa de frutos de macaúba desidratados em diferentes condições e armazenados por até 120 dias. Os frutos de macaúba "Acrocomia totai" foram coletados, sanitizados, desidratados nas temperaturas de $40,50,60$ e $70{ }^{\circ} \mathrm{C}$ e armazenados em sacos de ráfia em temperatura ambiente. A secagem em temperaturas mais elevadas resultou em polpas com coloração mais escura e alaranjada, porém com menor acidez titulável e índice de acidez do óleo da polpa. Durante o armazenamento houve aumento do índice de acidez do óleo da polpa e redução do teor de ácido ascórbico e carotenoides da polpa dos frutos. A secagem e o tempo de

1 M.e em Saúde e Desenvolvimento na Região Centro-Oeste, Universidade Federal de Mato Grosso do Sul, UFMS, Campo Grande, MS, Brasil. E-mail: vanessamandu@hotmail.com

2 Prof $^{\text {as }}$ Dr $^{\text {as }}$., UFMS, Campo Grande, MS, Brasil. E-mail: ritaaguimaraes@gmail.com; pirescamposraquel@gmail.com; priscila. hiane@ufms.br; juliana.donadon@ufms.br

3 Pesquisador, Empresa Brasileira de Pesquisa Agropecuária, EMBRAPA Produtos e Mercado, Ponta Grossa, PR, Brasil. E-mail: aurelio.borsato@embrapa.br

* Autor para correspondência 
armazenamento dos frutos diminuíram o teor de ácido ascórbico e de carotenoides da polpa. A secagem em temperaturas mais baixas resultou em polpas com maior capacidade de sequestrar radicais livres. A qualidade do óleo da polpa foi comprometida pela secagem e tempo de armazenamento. Frutos de macaúbas recém coletados podem ser desidratados a $40,50,60$ ou $70{ }^{\circ} \mathrm{C}$ e armazenados por até 120 dias, sem comprometer a qualidade do óleo da amêndoa.

Palavras-chave: Acrocomia totai. Antioxidante. Temperatura. Desidratação. Óleo.

\section{Introduction}

Bocaiuva, also known as macaúba, is the fruit of a native palm tree of the genus Acrocomia, found in all regions of Brazil, in the phytogeographic biomes of Amazon, Caatinga, Cerrado, Atlantic Forest and Pantanal (Leitman, Soares, Henderson, Noblick, \& Martins, 2018). Two of the six species are the most largely used by local populations in the country: $A$. aculeata and A. totai (Silva, 2017).

Macaúba has a high lipid content $30.38-44.20 \%$ in the pulp and $41.10-55.55 \%$ in the nut and nutritional properties that enable its use as food. In the pulp, these fats consist mostly of monounsaturated fatty acids, especially oleic acid (omega 9), whereas in the nut, saturated fatty acids predominate, with lauric acid occurring in the highest percentage (Munhoz, Guimarães, Nozaki, Sanjinez-Argandoña, $\&$ Macedo, 2018). The fruit contains $\beta$-carotene and $\alpha$-tocopherol, which are natural antioxidants and precursors of vitamins A and E, respectively (Coimbra \& Jorge, 2011). These substances are related to reduced risk of cardiovascular disease and non-transmissible chronic diseases like cancer (Fisk II, 2011).

The use of macaúba fruits, especially in the Brazilian state of Mato Grosso do Sul, has a strong socioeconomic and environmental appeal, as it is an abundant natural resource with the potential to be used for various purposes, mainly as a food. It is of extreme importance for the conservation of biodiversity and income generation for extractive communities and family farmers (Silva, Campos, Borsato, Cândido, \& Donadon, 2018). The macaúba fruit can be consumed fresh or processed as a meal (Kopper, Saravia, Ribani, \& Lorenzi, 2009) obtained by manual or mechanical extraction (I.
A. Amaral, Loubet Filho, Cavalheiro, Galvani, \& Santos, 2019). According to P. B. Silva et al. (2019), the mechanically extracted edible oil from its pulp has antidiabetic and antioxidant properties, which enable its inclusion in functional foods.

Due to the commercial potential of macaúba as raw material for the pharmaceutical, cosmetic, food and biofuel industries (Chuba-Machado, 2018) and the impossibility of immediately processing the fruit harvested from the season crop, drying is an essential step for storage, since, as described by Ball (2013), it allows the removal of part of the water contained in agricultural products. In this way, field losses are minimized and the product can be stored longer, preventing the development of microorganisms.

Increased temperatures reduce the drying time of macaúba fruit (Gonçalves, 2018), speeding up this process during the season harvest and reducing the subsequent waiting time, thereby preventing deterioration. However, Gonçalves (2018) stated that increases in the drying temperature affected oxidative stability and the acidity index of oils extracted from the macaúba mesocarp for biofuel production. The authors then recommended a drying temperature of up to $56.6^{\circ} \mathrm{C}$

On these bases, the present study examined the chemical and oxidative stability of macaúba fruit dried in different air conditions and stored for up to 120 days.

\section{Material and Methods}

Macaúba branches were harvested manually after physiological development, in the municipality of Corumbá - MS, Brazil, in December 2016. Injured, 
green or senescing fruits were discarded. Whole fruits with a predominant yellow color in the peel were sanitized with chlorinated water $\left(200 \mathrm{mg} \mathrm{L}^{-1}\right)$ for $10 \mathrm{~min}$. Water on the fruit surface was dried on a countertop lined with paper towel. The fruits were divided into two batches: Batch 1, containing approximately $3 \mathrm{~kg}$ of fruit, was used for the physicochemical characterization, whereas Batch 2, with $100 \mathrm{~kg}$, was used for drying in different air conditions.

The fresh fruit was characterized physically in terms of equatorial and longitudinal diameters, total weight, water content and peel and pulp color, by separating 25 units for the assessments. External diameter was measured using a digital caliper (ZAAS 6), with results expressed in millimeters. The fruit, peel (epicarp), pulp (mesocarp) and seed (nut) weights were determined using an analytical balance (AND HR-202), with results expressed in grams. The fruit yields as peel, pulp and nut were determined by subtracting the peel, pulp and nut weights from the total weight, respectively, and correlating each fraction to the total mass; results were expressed in percentage terms.

The water content of whole fresh fruits was determined in accordance with V. M. Silva et al. (2017), while the water activity of the fresh pulp was measured using a water activity meter (Hydropalm Aw1).

Fresh peel and pulp color was determined using a spectrophotometer (CM-2300d, Konica Minolta), with results expressed as $L^{*}, a^{*}$ and $b^{*}$.

To determine the maturation stage of fresh fruits, as proposed by the Instituto Adolfo Lutz (2008), the pulps were evaluated for soluble solids content (SS), titratable acidity (TA; method 312 IV), SS/TA ratio and $\mathrm{pH}$, in three replicates.

The fresh-fruit pulp was characterized regarding the lipid contents (method 032 IV) and the pulp and nut oils were evaluated for the acidity, peroxide and iodine indices, methods 325 IV, 326 IV and 329 IV of the Instituto Adolfo Lutz (2008). To determine these indices, the lipids of both fractions (pulp and nut) were cold-extracted by immersing the sample, inside a filter-paper cartridge, in petroleum ether (boiling point $30-40^{\circ} \mathrm{C}$ ) for $24 \mathrm{~h}$, without heating, and separating the solvent in a rotary evaporator (892 d, Fisatom, Brazil).

The ascorbic acid content of the fresh pulp was determined by method 365 IV of IAL (2008), whereas the carotenoid content was measured as proposed by Rodriguez-Amaya (2001). The antioxidant activity of the pulp was measured by method DPPH (2,2-diphenyl-1-picrylhydrazyl), in an adaptation suggested by Fukumoto and Mazza (2000), using hydrocetonic extracts (70\% acetone), according to Roesler et al. (2007). Analyses were carried out on microplates by serially diluting the sample. The results for ascorbic acid, carotenoids and IC 50 were corrected for samples with a $12 \%$ wet basis (wb) moisture content.

The macaúba fruits were artificially dried in a forced-air oven (Marconi, MA-035/5) at the temperatures of $40,50,60$ and $70{ }^{\circ} \mathrm{C}$. The decrease in water content throughout the drying process was monitored by the gravimetric method, which required knowledge of the initial water content of the product, until the desired water content was reached $(<15 \% \mathrm{wb})$.

Drying-air temperature was monitored using a thermometer that was installed in the dryer, and air relative air humidity was calculated based on the basic principles of psychrometry, by monitoring the internal (temperature) and external (temperature and relative humidity) air conditions of the dryer. The obtained values were then used to determine air relative humidity in the dryer, using Grapsi_draw 4.0 software. The average temperature and relative humidity values in the dryer were $41.33 \pm 1.54{ }^{\circ} \mathrm{C}$ and $31.72 \pm 2.99 \% ; 52.2 \pm 2.39{ }^{\circ} \mathrm{C}$ and $18.96 \pm 2.08 \%$; $59.1 \pm 0.74{ }^{\circ} \mathrm{C}$ and $14.21 \pm 2.07 \%$; and $70 \pm 0.1{ }^{\circ} \mathrm{C}$ and $8.50 \pm 0.66 \%$ when they were regulated at $40,50,60$ and $70{ }^{\circ} \mathrm{C}$, respectively. Fruit drying time at $40{ }^{\circ} \mathrm{C}$ was $91 \mathrm{~h}$; at 50 and $60{ }^{\circ} \mathrm{C}, 42 \mathrm{~h}$; and at $70{ }^{\circ} \mathrm{C}, 27 \mathrm{~h}$ (Figure 1). 
After drying, the fruits were packed in raffia bags and stored at room temperature for up to 120 days. Temperature and relative humidity during the storage period were monitored using a thermohygrometer.
The temperature in the storage room ranged between $25-30{ }^{\circ} \mathrm{C}$ and relative humidity was $61 \%$. The minimum air relative humidity dropped from 54 to $40 \%$, whereas the maximum humidity did not vary considerably, ranging between 57 and $62 \%$.

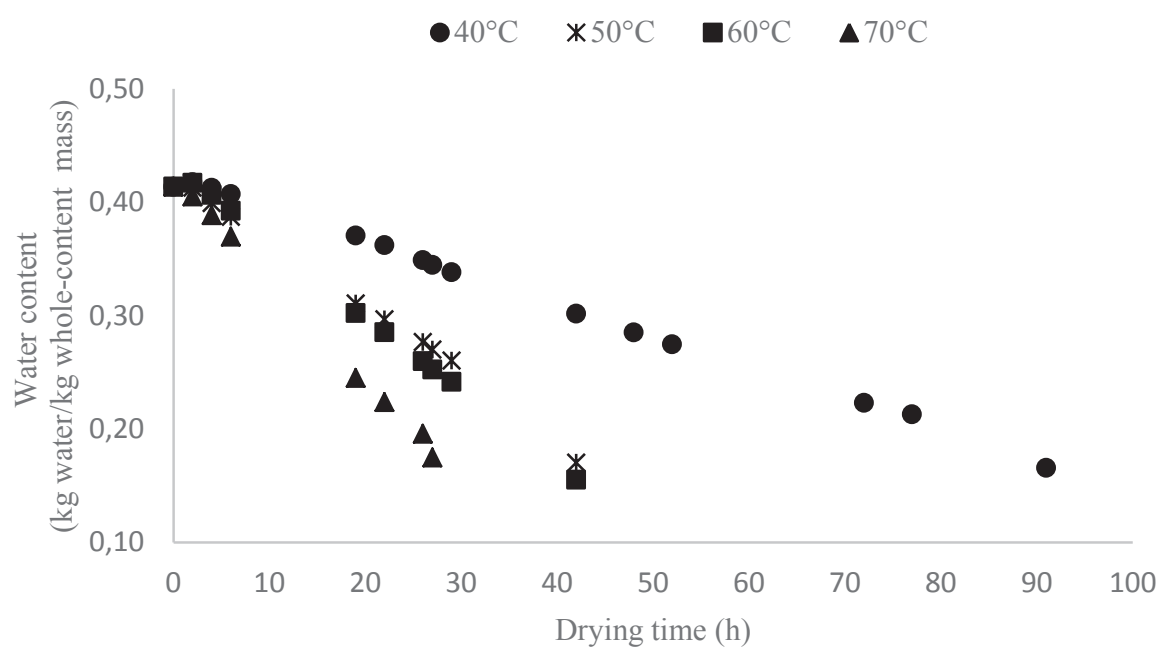

Figure 1. Drying curve of macaúba fruits dried at different temperatures.

During storage, the pulps of the fruits from each treatment were chemically evaluated at $0,30,60$, 90 and 120 days (five periods) in three replicates, using $350 \mathrm{~g}$ of product per replicate. The pulp was evaluated for the water content, by the ovendrying method, until reaching a constant weight (IAL, 2008); water activity (Hydropalm Aw 1); color, by spectrophotometry (Konica Minolta CM2300d); lipid content (method 032 IV); titratable acidity, using alcohol as a solvent (to facilitate sample dilution and prevent the formation of lumps) (method 415 IV); ascorbic acid, by method 365 IV (IAL, 2008); total carotenoids (Rodriguez-Amaya, 2001); and antioxidant activity (Roesler et al., 2007). Values were expressed as $12 \%$ (wb) moisture.

The pulp and nut oils were evaluated for the acidity, peroxide and iodine indices, following methods 325 IV, 326 IV and 329 IV, respectively, of the IAL (2008). Lipids were cold-extracted using petroleum ether as solvent $\left(30-40^{\circ} \mathrm{C}\right)$ and separated in a rotary evaporator (Fisatom 802d, Brazil) (IAL, 2008).

The drying-storage experiment was set up as a completely randomized design with a $4 \times 5$ factorial arrangement represented by four drying temperatures (40, 50, 60 and $70{ }^{\circ} \mathrm{C}$ ) and five storage times $(0,30,60,90$ and 120 days), in three replicates. Each replicate was evaluated in triplicate. Data were subjected to analysis of variance and means were compared by Tukey's test at the $1 \%$ probability level. When the Treatment $\times$ Storage time interactions were significant, the interaction effects were decomposed with the factors analyzed within each level of another factor.

\section{Results and Discussion}

The macaúba fruits showed an individual weight of $29.83 \pm 1.48 \mathrm{~g}$ and equatorial and longitudinal diameters of $32.94 \pm 2.79$ and $32.18 \pm 2.27 \mathrm{~mm}$. 
Similar values were found in macaúba fruits harvested in Dourados-MS (33.39 and $34.68 \mathrm{~mm}$, respectively) and Presidente Epitácio - SP (31.65 and $33.14 \mathrm{~mm}$, respectively), with no significant differences occurring between both locations (Sanjinez-Argandoña \& Chuba, 2011). Higher diameter values were reported in macaúba fruits in Belo Horizonte - MG, 44.70 \pm 2.2 and $43.60 \pm 1.74$ $\mathrm{mm}$, respectively) (Queiroz, 2016). The great variability found in those physical traits is possibly related to genetic diversity and soil-climatic factors.

The whole fruits showed $41.36 \pm 3.23 \%$ moisture and the pulp showed a water activity of $0.94 \pm 0.01 \%$. Likewise, the water activity in macaúba pulp found by Sanjinez-Argandoña and Chuba (2011) was also high (0.90 to 0.95$)$. Storage resistance is associated with the metabolic activity of tissues, which decreases as the water content in the plant tissue is reduced (Chitarra \& Chitarra, 2005). Water activity is characterized by the available water content, which is related to enzymatic activity and microbial proliferation. According to Ferreira Neto, Figueirêdo and Queiroz (2005), most microbiological agents grow in medium with water activity in the range of 0.90 to 0.99 .

The peel and pulp of the fresh fruits showed positive $\mathrm{a}^{*}($ peel $=12.73 \pm 3.81 ;$ pulp $=14.29 \pm 1.02)$ and $\mathrm{b}^{*}$ (peel $=35.87 \pm 3.58$; pulp $=46.61 \pm 5.85$ ) values, which represent a red-to-yellow tone, respectively. The higher $b^{*}$ values in comparison to $\mathrm{a}^{*}$ indicate a predominant yellow color. However, the pulp shoed elevated lightness values $\left(\mathrm{L}^{*}=\right.$ $67.74 \pm 0.67)$, resulting in a lighter yellow tone than the peel $\left(\mathrm{L}^{*}=46.61 \pm 5.85\right)$.

Fresh macaúba pulp showed SS and TA values

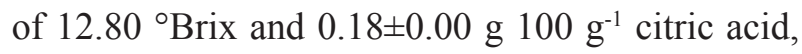
respectively. The SS/TA ratio was 71.11 , which indicates the stage of maturation, considering the SS content and the low TA content; and also a sweet pulp, which can thus be used in the making of ice creams and jams. The $\mathrm{pH}$ value $(5.74 \pm 0.02)$ suggests a pulp of low acidity, similar to the pulp of fruits harvested in the Pantanal region of MS State (Souza, Cuellar, Donadon, \& Guimarães, 2019). These results confirmed the adequate time of harvest adopted in this study.

The lipid content of fresh macaúba pulp was

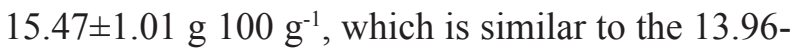
$15.77 \%$ found by Silva et al. (2018) in the pulp of macaúba fruits obtained in the state of Mato Grosso do Sul (13.96-15.77\%) and lower than the $44.2 \pm 0.2 \%$ found by Queiroz (2016) in macaúba fruits in Rio Largo - AL.

The acidity, peroxide and iodine values of fresh macaúba pulp oil were $5.31 \mathrm{mg} \mathrm{NaOH} \mathrm{g}^{-1}, 3.73 \mathrm{mEq}$ $\mathrm{kg}^{-1}$ and $56.90 \mathrm{~g} \mathrm{I}_{2} 100 \mathrm{~g}^{-1}$, respectively, whereas the respective nut oil indices were $0.54 \mathrm{mg} \mathrm{NaOH} \mathrm{g}^{-1}$, $0.00 \mathrm{mEq} \mathrm{kg}^{-1}$ and $18.36 \mathrm{~g} \mathrm{I}_{2} 100 \mathrm{~g}^{-1}$. These acidity and peroxide values are within the accepted range for palm oil $\left(<10 \mathrm{mg} \mathrm{KOH} \mathrm{g}^{-1}\right)$ and virgin olive oil $\left(<20 \mathrm{mEq} \mathrm{kg}{ }^{-1}\right)$, respectively, and the iodine index of the pulp oil is lower than the $73.25 \pm 0.10$ obtained by Oliveira (2016) in macaúba pulp oil in São Paulo. The iodine index increases proportionally to the level of unsaturation; accordingly, a higher level of unsaturated fatty acids was found in the pulp compared to the nut. Pulp oil consists mostly of long-chain fatty acids (F. P. Amaral, Broetto, Batistella, \& Jorge, 2011).

Fresh macaúba pulp showed an ascorbic acid content of $14.54 \pm 0.00 \mathrm{mg} 100 \mathrm{~g}^{-1}$, which is similar to the $11.46 \mathrm{mg} .100 \mathrm{~g}^{-1}$ found in macaúba pulp harvested in Presidente Epitácio - SP, but conflicting with the $34.57 \mathrm{mg} .100 \mathrm{~g}^{-1}$ observed in macaúba fruit in Dourado - MS (Sanjinez-Argandoña \& Chuba, 2011). The total carotenoid content of the pulp was $77.69 \pm 0.34 \mu \mathrm{g} \mathrm{g}^{-1}$, which is close to the value obtained by Souza, Cueller, Donadon and Guimarães (2019) in the pulp of macaúba fruit harvested in the Pantanal region of MS.

Microbial activity in the fresh pulp was high $\left(\mathrm{IC}_{50}=0.49 \pm 0.00 \mathrm{mg} \mathrm{mL}^{-1}\right)$, considering that lower values indicate greater antioxidant capacity (Luzia \& Jorge, 2010). 
The water content of the whole fruit and the water activity in the pulp of macaúba fruits dried in different air conditions $\left(40,50,60\right.$ and $\left.70{ }^{\circ} \mathrm{C}\right)$ did not differ between the temperature groups $(\mathrm{P}<0.01)$, with moisture values between 11.24 and $12.01 \%$. There was no statistical difference for these values during the storage period (30, 60, 90 and 120 days) (Table 1). Therefore, the variations in air relative humidity during storage did not interfere with the water content of the fruits during the evaluated periods. The observed water content values were lower than the maximum limit (15\%) for meals (RDC $\mathrm{n}^{\circ} 263$ of September 22, 2005), whereas the Aw values were lower than the minimum limit (0.60) for the development of microorganisms in dried products (Pinto \& Neves, 2010).

Table 1

Water content of the fruit, Aw, color $\left(L^{*}, a^{*}, b^{*}\right)$ and titratable acidity of macaúba pulp dried in different air conditions and stored for up to 120 days

\begin{tabular}{ccccccc}
\hline Treatment & $\begin{array}{c}\text { Moisture } \\
(\%) * *\end{array}$ & Aw & $\mathrm{L}^{*}$ & $\mathrm{a}^{*}$ & $\mathrm{~b}^{*}$ & $\begin{array}{c}\text { Acidity** } \\
\left(\mathrm{g} 100 \mathrm{~g}^{-1}\right)\end{array}$ \\
\hline $40^{\circ} \mathrm{C}$ & $12.01 \mathrm{a}$ & $0.36 \mathrm{a}$ & $64.87 \mathrm{a}$ & $9.73 \mathrm{~b}$ & $32.11 \mathrm{a}$ & $0.36 \mathrm{~b}$ \\
$50^{\circ} \mathrm{C}$ & $11.90 \mathrm{a}$ & $0.38 \mathrm{a}$ & $64.93 \mathrm{a}$ & $9.62 \mathrm{~b}$ & $28.83 \mathrm{~b}$ & $0.42 \mathrm{a}$ \\
$60^{\circ} \mathrm{C}$ & $11.24 \mathrm{a}$ & $0.37 \mathrm{a}$ & $64.45 \mathrm{a}$ & $9.91 \mathrm{~b}$ & $27.64 \mathrm{~b}$ & $0.33 \mathrm{c}$ \\
$70^{\circ} \mathrm{C}$ & $11.27 \mathrm{a}$ & $0.33 \mathrm{a}$ & $59.54 \mathrm{~b}$ & $11.66 \mathrm{a}$ & $25.07 \mathrm{~b}$ & $0.23 \mathrm{~d}$ \\
\hline $\mathrm{F}$ test & $1.30 \mathrm{NS}$ & $2.79 \mathrm{NS}$ & $142.50^{* *}$ & $75.53 * *$ & $153.43^{* *}$ & $339.11^{* *}$ \\
\hline Time (days) & & & & & & \\
\hline 0 & $13.18 \mathrm{a}$ & $0.35 \mathrm{a}$ & $61.95 \mathrm{~b}$ & $11.11 \mathrm{a}$ & $30.67 \mathrm{a}$ & $0.24 \mathrm{~d}$ \\
30 & $11.02 \mathrm{a}$ & $0.36 \mathrm{a}$ & $64.48 \mathrm{a}$ & $9.99 \mathrm{~b}$ & $29.27 \mathrm{a}$ & $0.30 \mathrm{c}$ \\
60 & $10.89 \mathrm{a}$ & $0.35 \mathrm{a}$ & $64.47 \mathrm{a}$ & $9.84 \mathrm{c}$ & $27.29 \mathrm{~b}$ & $0.36 \mathrm{~b}$ \\
90 & $10.83 \mathrm{a}$ & $0.35 \mathrm{a}$ & $63.79 \mathrm{~b}$ & $9.96 \mathrm{~b}$ & $27.86 \mathrm{~b}$ & $0.36 \mathrm{~b}$ \\
120 & $12.12 \mathrm{a}$ & $0.39 \mathrm{a}$ & $62.55 \mathrm{~b}$ & $10.27 \mathrm{~b}$ & $26.97 \mathrm{~b}$ & $0.41 \mathrm{a}$ \\
\hline $\mathrm{F}$ test & $6.60 \mathrm{NS}$ & $1.28 \mathrm{NS}$ & $21.90 * *$ & $40.18 * *$ & $35.12 * *$ & $176.03 * *$ \\
\hline Treatment $\times$ Time & $0.95 \mathrm{NS}$ & $1.26 \mathrm{NS}$ & $7.10 * *$ & $32.09 * *$ & $11.58^{* *}$ & $25.82 * *$ \\
\hline $\mathrm{CV}(\%)$ & 0.06 & 0.05 & 0.03 & 0.03 & 0.08 & 0.19 \\
\hline
\end{tabular}

Means followed by the same lowercase letter in the columns do not differ from each other according to Tukey's test ( $\mathrm{P}<0.01)$.

**Calculation, $12 \%$ moisture base.

In the analysis of pulp color parameters, significant differences were found for the interaction between drying temperatures and storage times. The fruits which had been dried at $70{ }^{\circ} \mathrm{C}$ showed significant differences for pulp color, with the lowest $\mathrm{L}^{*}$ value, indicating a darker tone than the others, caused by the increase in drying temperature. The lightness of the pulp of macaúba fruits dried at 60 and $70{ }^{\circ} \mathrm{C}$ did not change during storage (Table 2). When the storage time of macaúba dried at 40 and $50{ }^{\circ} \mathrm{C}$ was evaluated, lighter pulps were observed when the fruits were dried at $40{ }^{\circ} \mathrm{C}$ and stored for 60 days and at $50{ }^{\circ} \mathrm{C}$ and stored for up to 30 days (Table 2).

Drying at $70{ }^{\circ} \mathrm{C}$ resulted in pulps with a redder tone compared to those of fruits dried at lower temperatures (Table 1). During storage, the $a^{*}$ values of the pulps of the fruits dried at $40{ }^{\circ} \mathrm{C}$ decreased, indicating a reduction of red intensity. This trend was also noted for the pulps of the fruits dried at $50^{\circ} \mathrm{C}$ and stored for up to 90 days. At 120 
days of storage, the $\mathrm{a}^{*}$ values of the pulp of fruits dried at $50{ }^{\circ} \mathrm{C}$ did not differ from those found in the pulps of fruits newly dried (0 days) at the same temperature. The pulp a* values did not change throughout storage in the fruits dried at 60 and 70 ${ }^{\circ} \mathrm{C}$ (Table 2).

The $b^{*}$ values were higher in the pulps from the fruits dried at $40{ }^{\circ} \mathrm{C}$ and stored for up to 30 days (Table 1). Higher $b^{*}$ values mean yellower pulps. The decomposition of the significant interactions revealed that the $b^{*}$ values in the pulp decreased during the storage of fruits dried at 40 and $50{ }^{\circ} \mathrm{C}$, indicating a reduction in the yellow tone. The pulps of fruits dried at 60 and $70{ }^{\circ} \mathrm{C}$ showed no significant changes in color during storage (Table 2).

Table 2

Changes in color $\left(\mathrm{L}^{*}, \mathrm{a}^{*}\right.$ and $\left.\mathrm{b}^{*}\right)$ and soluble titratable acidity of macaúba pulp dried in different air conditions and stored for up to 120 days

\begin{tabular}{|c|c|c|c|c|c|}
\hline \multirow{2}{*}{ Treatment } & \multicolumn{5}{|c|}{ Storage time (days) } \\
\hline & 0 & 30 & 60 & 90 & 120 \\
\hline \multicolumn{6}{|c|}{ Lightness } \\
\hline $40^{\circ} \mathrm{C}$ & $62.32 \mathrm{Ba}$ & $65.10 \mathrm{Ba}$ & $67.82 \mathrm{Aa}$ & $65.42 \mathrm{Ba}$ & $63.70 \mathrm{Ba}$ \\
\hline $50^{\circ} \mathrm{C}$ & $62.15 \mathrm{Ba}$ & $67.49 \mathrm{Aa}$ & $65.46 \mathrm{Ba}$ & $66.06 \mathrm{Ba}$ & $63.47 \mathrm{Ba}$ \\
\hline $60^{\circ} \mathrm{C}$ & $63.92 \mathrm{Aa}$ & $64.64 \mathrm{Aa}$ & $65.79 \mathrm{Aa}$ & $64.81 \mathrm{Aa}$ & $63.11 \mathrm{Aa}$ \\
\hline $70^{\circ} \mathrm{C}$ & $59.40 \mathrm{Aa}$ & $60.70 \mathrm{Ab}$ & $58.81 \mathrm{Ab}$ & $58.85 \mathrm{Ab}$ & $59.92 \mathrm{Ab}$ \\
\hline \multicolumn{6}{|c|}{$a^{*}$} \\
\hline $40^{\circ} \mathrm{C}$ & $12.42 \mathrm{Aa}$ & $9.66 \mathrm{Bb}$ & $8.58 \mathrm{Bc}$ & $9.22 \mathrm{Bb}$ & $8.79 \mathrm{Bc}$ \\
\hline $50^{\circ} \mathrm{C}$ & $10.54 \mathrm{Ab}$ & $8.50 \mathrm{Bc}$ & $9.25 \mathrm{Bb}$ & $8.97 \mathrm{Bb}$ & $10.84 \mathrm{Ab}$ \\
\hline $60^{\circ} \mathrm{C}$ & $9.66 \mathrm{Ac}$ & $10.25 \mathrm{Ab}$ & $9.71 \mathrm{Aa}$ & $9.78 \mathrm{Ab}$ & $10.15 \mathrm{Ab}$ \\
\hline $70^{\circ} \mathrm{C}$ & $11.81 \mathrm{Aa}$ & $11.53 \mathrm{Aa}$ & $11.80 \mathrm{Aa}$ & $11.88 \mathrm{Aa}$ & $11.29 \mathrm{Aa}$ \\
\hline \multicolumn{6}{|c|}{$b^{*}$} \\
\hline $40^{\circ} \mathrm{C}$ & $38.25 \mathrm{Aa}$ & $33.06 \mathrm{Ba}$ & $29.54 \mathrm{Ca}$ & $31.00 \mathrm{Ca}$ & $28.69 \mathrm{Ca}$ \\
\hline $50^{\circ} \mathrm{C}$ & $31.43 \mathrm{Ab}$ & $29.03 \mathrm{Ba}$ & $27.73 \mathrm{Ba}$ & $28.86 \mathrm{Ba}$ & $27.09 \mathrm{Ba}$ \\
\hline $60^{\circ} \mathrm{C}$ & $28.64 \mathrm{Ab}$ & $28.09 \mathrm{Aa}$ & $27.54 \mathrm{Aa}$ & $26.48 \mathrm{Aa}$ & $27.43 \mathrm{Aa}$ \\
\hline $70^{\circ} \mathrm{C}$ & $24.35 \mathrm{Ab}$ & $26.88 \mathrm{Aa}$ & $24.34 \mathrm{Aa}$ & $25.11 \mathrm{Aa}$ & $24.68 \mathrm{Aa}$ \\
\hline \multicolumn{6}{|c|}{ Soluble titratable acidity $\left(\mathrm{g}\right.$ citric acid $\left.100 \mathrm{~g}^{-1}\right)$} \\
\hline $40^{\circ} \mathrm{C}$ & $0.21 \mathrm{Cb}$ & $0.31 \mathrm{Bb}$ & $0.42 \mathrm{Aa}$ & $0.40 \mathrm{Aa}$ & $0.46 \mathrm{Ab}$ \\
\hline $50^{\circ} \mathrm{C}$ & $0.28 \mathrm{Db}$ & $0.40 \mathrm{Da}$ & $0.42 \mathrm{Ca}$ & $0.44 \mathrm{Ba}$ & $0.57 \mathrm{Aa}$ \\
\hline $60^{\circ} \mathrm{C}$ & $0.28 \mathrm{Ba}$ & $0.28 \mathrm{Bb}$ & $0.36 \mathrm{Aa}$ & $0.35 \mathrm{Aa}$ & $0.35 \mathrm{Ac}$ \\
\hline $70^{\circ} \mathrm{C}$ & $0.21 \mathrm{Ab}$ & $0.21 \mathrm{Ac}$ & $0.25 \mathrm{Ab}$ & $0.25 \mathrm{Ab}$ & $0.25 \mathrm{Ad}$ \\
\hline
\end{tabular}

Means followed by the same lowercase letter in the column and uppercase letter in the row do not differ from each other according to Tukey's test $(\mathrm{P}<0.01)$.

By comparing the results of pulp color in the dried compared to the fresh fruit $(\mathrm{L}=61.74 \pm 0.67$, $\mathrm{a}^{*}=14.29 \pm 1.02$ and $\left.\mathrm{b}^{*}=46.61 \pm 5.85\right)$, we observe that the former showed lower $a^{*}$ and $b^{*}$ values (Table 1). When the values were projected onto the color diagram (hue and saturation), the dried pulps were found to have a more orangish tone as temperature and storage time increased.

The pulp of fruits dried at 60 and $70{ }^{\circ} \mathrm{C}$ showed lower titratable acidity (Table 1), indicating that 
the lower rate of decrease in water content at the temperatures of 40 and $50^{\circ} \mathrm{C}$ and the longer exposure to heat until the expected water content was reached favored the degradation of lipids from the pulp and the release of free acids. In the fruits dried at 70 ${ }^{\circ} \mathrm{C}$, pulp acidity remained stable throughout storage, whereas in the fruits dried at 40,50 and $60{ }^{\circ} \mathrm{C}$, the acidity contents increased, indicating degradation of the existing lipids (Table 2).

The results presented in Tables 3 and 4 reveal that higher drying temperatures and longer storage times resulted in decreased ascorbic acid and carotenoid contents. Accordingly, the pulps had a higher freeradical sequestering ability when the fruits were dried at $40-50{ }^{\circ} \mathrm{C}$ and stored for up to 90 days. The decomposition of the significant interactions showed that the ascorbic acid contents did not change in the fruits dried at $70{ }^{\circ} \mathrm{C}$, during storage (Table 3). Results for the ascorbic acid content were close to those found by Reis, Figueiredo, Ferraz and Freitas (2017) in seedless acerola (Malpighia emarginata) meal.

Table 3

Bioactive compounds in macaúba pulp dried in different air conditions and stored for up to 120 days (20-30 ${ }^{\circ} \mathrm{C}$; 40-61\% RH)

\begin{tabular}{|c|c|c|c|}
\hline Treatment & $\begin{array}{l}\text { Ascorbic acid* } \\
\left(\mathrm{mg} 100 \mathrm{~g}^{-1}\right)\end{array}$ & $\begin{array}{l}\text { Carotenoids* } \\
\left(\mu \mathrm{g} \mathrm{g}^{-1}\right)\end{array}$ & $\begin{array}{l}\text { Antioxidant activity* } \\
\mathrm{IC}_{50}\left(\mathrm{mg} \mathrm{mL}^{-1}\right)\end{array}$ \\
\hline $40^{\circ} \mathrm{C}$ & $5.45 \mathrm{a}$ & $36.10 \mathrm{a}$ & $6.59 \mathrm{~b}$ \\
\hline $50^{\circ} \mathrm{C}$ & $3.85 b$ & $29.14 \mathrm{~b}$ & $7.02 \mathrm{~b}$ \\
\hline $60{ }^{\circ} \mathrm{C}$ & $3.95 b$ & $23.38 \mathrm{~d}$ & $9.18 \mathrm{a}$ \\
\hline $70^{\circ} \mathrm{C}$ & $3.91 \mathrm{~b}$ & $25.86 \mathrm{c}$ & $7.74 \mathrm{a}$ \\
\hline F test & $86.59^{* *}$ & & \\
\hline \multicolumn{4}{|l|}{ Time (days) } \\
\hline 0 & $5.24 \mathrm{a}$ & $41.45 \mathrm{a}$ & $6.49 \mathrm{~b}$ \\
\hline 30 & $4.90 \mathrm{a}$ & $28.74 \mathrm{~b}$ & $6.61 \mathrm{~b}$ \\
\hline 60 & $4.33 b$ & $26.70 \mathrm{c}$ & $6.33 \mathrm{~b}$ \\
\hline 90 & $3.43 b$ & $25.46 \mathrm{c}$ & $8.63 \mathrm{a}$ \\
\hline 120 & $3.56 \mathrm{c}$ & $20.74 \mathrm{~d}$ & $10.10 \mathrm{a}$ \\
\hline F test & $72.93 * *$ & $406.89 * *$ & $11.13 * *$ \\
\hline Treatment $\times$ time & $21.15^{* *}$ & $118.29 * *$ & $3.84 * *$ \\
\hline CV $(\%)$ & 0.21 & 0.23 & 0.18 \\
\hline
\end{tabular}

Means followed by the same lowercase letter in the columns do not differ from each other according to Tukey's test at the $1 \%$ probability level.

*Calculation, $12 \%$ moisture base.

Results for ascorbic acid and carotenoids in the fresh pulp $\left(14.54 \pm 0.00 \mathrm{mg} 100 \mathrm{~g}^{-1}\right.$ and $77.69 \pm 0.37 \mu \mathrm{g}$ $\mathrm{g}^{-1}$, respectively) were higher than those found after drying, reinforcing the fact that the drying process reduces those contents. In a study on macaúba jam, the total carotenoid contents found in the macaúba pulp and jam with passion fruit were 58.29 and
$11.44 \mathrm{mg} 100 \mathrm{~g}^{-1}$, respectively, demonstrating the reduction post-processing. In the same study, the ascorbic acid content detected in macaúba pulp was minimal, with the different morphotypes found in the state of Mato Grosso do Sul providing different pulp color tones and compositions (Souza, Cueller, Donadon \& Guimarães, 2019). 
The total carotenoid content was statistically higher in the pulp of the fruits that were dried at 40 and $50{ }^{\circ} \mathrm{C}$. Similarly, Chuba-Machado (2018) reported that pulp of macaúba fruits dried at $50{ }^{\circ} \mathrm{C}$ showed higher carotenoid values (64.6 to $78.3 \mu \mathrm{g}$ $\left.\mathrm{g}^{-1}\right)$ than samples of fruits dried at $70{ }^{\circ} \mathrm{C}$ (56.9 to $\left.62.6 \mu \mathrm{g} \mathrm{g}^{-1}\right)$.

The decreasing carotenoid contents may explain the results obtained for color, where the dried fruits showed lower $a^{*}$ and $b^{*}$ values compared to the fresh fruits. This was possibly due to the degradation of those pigments, which confer tones that range from red to yellow (Chitarra \& Chitarra, 2005).

In this way, the less intense color corresponded to a lower carotenoid content. All treatments exhibited a reduction in total carotenoid content throughout the storage period. According to Rios,
Antunes and Bianchi (2009), throughout the storage period, carotenoids may be isomerized and oxidized due to their unstable structure, and the increase in temperature and exposure to light are related to oxidation or decomposition of the carotenoid chain.

Compared to the results for $\mathrm{IC}_{50}$ obtained with the fresh pulp $\left(0.49 \pm 0.00 \mathrm{mg} \mathrm{mL}^{-1}\right)$, fruit drying was shown to reduce free-radical sequestering ability. The lower $\mathrm{IC}_{50}$ values in the pulp of fruits dried at $40-50{ }^{\circ} \mathrm{C}$ indicated greater free-radical sequestering ability, which was not observed in the fruits dried at $60-70{ }^{\circ} \mathrm{C}$. During storage, the values remained stable for up to 90 days at the temperatures of 40 and 60 ${ }^{\circ} \mathrm{C}$ and up to 60 days at $70{ }^{\circ} \mathrm{C}$ (Table 3). At $90-120$ days of storage, higher values were seen (Table 4), suggesting a lower free-radical sequestering ability.

\section{Table 4}

Change in ascorbic acid and carotenoid contents and antioxidant activity of pulp of macaúba fruit dried in different air conditions and stored for up to 120 days $\left(20-30{ }^{\circ} \mathrm{C} ; 40-61 \% \mathrm{RH}\right)$

\begin{tabular}{|c|c|c|c|c|c|}
\hline \multirow{2}{*}{ Treatment } & \multicolumn{5}{|c|}{ Storage time (days) } \\
\hline & 0 & 30 & 60 & 90 & 120 \\
\hline \multicolumn{6}{|c|}{ Ascorbic acid* $\left(\mathrm{mg} 100 \mathrm{~g}^{-1}\right)$} \\
\hline $40^{\circ} \mathrm{C}$ & $7.53 \mathrm{Aa}$ & $7.13 \mathrm{Aa}$ & $5.16 \mathrm{Ba}$ & $3.74 \mathrm{Ca}$ & $3.71 \mathrm{Ca}$ \\
\hline $50{ }^{\circ} \mathrm{C}$ & $4.54 \mathrm{Ab}$ & $4.41 \mathrm{Ab}$ & 4.37 Aa & 2.94 Ba & $3.01 \mathrm{Ba}$ \\
\hline $60^{\circ} \mathrm{C}$ & $5.20 \mathrm{Ab}$ & $4.43 \mathrm{Ab}$ & 3.37 $\mathrm{Bb}$ & $3.32 \mathrm{Ba}$ & $3.42 \mathrm{Ba}$ \\
\hline $70^{\circ} \mathrm{C}$ & $3.67 \mathrm{Ab}$ & $3.64 \mathrm{Ab}$ & $4.40 \mathrm{Aa}$ & 3.71 Aa & 4.11 Aa \\
\hline \multicolumn{6}{|c|}{ Carotenoids* $\left(\mu \mathrm{g} \mathrm{g}^{-1}\right)$} \\
\hline $40^{\circ} \mathrm{C}$ & $54.71 \mathrm{Aa}$ & $48.19 \mathrm{Aa}$ & $35.89 \mathrm{Aa}$ & $23.28 \mathrm{Bb}$ & $18.43 \mathrm{Bb}$ \\
\hline $50{ }^{\circ} \mathrm{C}$ & $49.95 \mathrm{Aa}$ & $16.32 \mathrm{Dc}$ & $30.30 \mathrm{Bb}$ & $25.97 \mathrm{Cb}$ & $23.13 \mathrm{Ca}$ \\
\hline $60^{\circ} \mathrm{C}$ & $30.93 \mathrm{Ab}$ & $25.40 \mathrm{Bb}$ & $18.57 \mathrm{Bc}$ & $21.33 \mathrm{Bb}$ & $20.66 \mathrm{Ba}$ \\
\hline $70^{\circ} \mathrm{C}$ & $30.20 \mathrm{Ab}$ & $25.04 \mathrm{Bb}$ & $22.05 \mathrm{Bc}$ & $31.27 \mathrm{Aa}$ & $20.73 \mathrm{Ba}$ \\
\hline \multicolumn{6}{|c|}{ Antioxidant activity* $\mathrm{IC}_{50}\left(\mathrm{mg} \mathrm{mL}^{-1}\right)$} \\
\hline $40^{\circ} \mathrm{C}$ & $4.97 \mathrm{Ba}$ & $6.89 \mathrm{Ba}$ & $5.83 \mathrm{Ba}$ & $4.44 \mathrm{Bb}$ & $10.80 \mathrm{Aa}$ \\
\hline $50{ }^{\circ} \mathrm{C}$ & $7.48 \mathrm{Aa}$ & $6.18 \mathrm{Aa}$ & 4.79 Aa & $10.16 \mathrm{Aa}$ & $6.47 \mathrm{Aa}$ \\
\hline $60^{\circ} \mathrm{C}$ & $8.05 \mathrm{Ba}$ & $7.77 \mathrm{Ba}$ & $9.01 \mathrm{Ba}$ & $8.72 \mathrm{Bb}$ & $12.37 \mathrm{Aa}$ \\
\hline $70^{\circ} \mathrm{C}$ & $5.45 \mathrm{Ba}$ & $5.61 \mathrm{Ba}$ & $5.68 \mathrm{Ba}$ & $11.20 \mathrm{Aa}$ & $10.74 \mathrm{Aa}$ \\
\hline
\end{tabular}

Means followed by the same lowercase letter in the columns and uppercase letter in the row do not differ from each other according to Tukey's test $(\mathrm{P}<0.01)$.

*Calculation, $12 \%$ moisture base. 
Ferreira, Santos, Costa and Gebara (2013) developed a shake-type beverage prepared from dry extract of macaúba pulp, obtained by freeze-drying. The beverage could be considered an innovative functional food, as it can reduce the risk of diseases, especially those related to excess free radicals.

The pulps from fruits dried at the different temperatures did not differ from each other for the

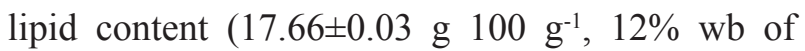
moisture). The oil content in the macaúba mesocarp was not influenced by drying-air temperature, either (Gonçalves, 2018).

In the pulp oil, drying the fruit at $70{ }^{\circ} \mathrm{C}$ resulted in the lowest acidity index (Table 5), which differed statistically from the results obtained at the other drying temperatures. The obtained values are within the threshold established by the Brazilian Health Surveillance Agency (Anvisa) (10 mg KOH g-1) (RDC $n^{\circ} 270$ of September 22, 2005) for virgin palm oil.

\section{Table 5}

Acidity, peroxide and iodine indices of pulp and nut oil from macaúba fruits dried in different air conditions and stored for up to 120 days

\begin{tabular}{|c|c|c|c|c|c|c|}
\hline \multirow[b]{2}{*}{ Treatment } & \multicolumn{3}{|c|}{ OIL (PULP) } & \multicolumn{3}{|c|}{ OIL (NUT) } \\
\hline & $\begin{array}{l}\text { Acidity index } \\
\left(\mathrm{mg} \mathrm{NaOH} \mathrm{g} \mathrm{g}^{-1}\right)\end{array}$ & $\begin{array}{c}\text { Peroxide } \\
\text { index } \\
\left(\mathrm{mEq} \mathrm{kg}^{-1}\right)\end{array}$ & $\begin{array}{l}\text { Iodine index } \\
\left(\mathrm{g} \mathrm{I}_{2} 100 \mathrm{~g}^{-1}\right)\end{array}$ & $\begin{array}{l}\text { Acidity index } \\
\left(\mathrm{mg} \mathrm{NaOH} \mathrm{g}^{-1}\right)\end{array}$ & $\begin{array}{c}\text { Peroxide } \\
\text { index } \\
\left(\mathrm{mEq} \mathrm{kg}^{-1}\right)\end{array}$ & $\begin{array}{l}\text { Iodine index } \\
\left(\mathrm{g} \mathrm{I}_{2} 100 \mathrm{~g}^{-1}\right)\end{array}$ \\
\hline $40^{\circ} \mathrm{C}$ & $12.62 \mathrm{~b}$ & $16.83 \mathrm{~b}$ & $60.32 \mathrm{a}$ & $0.14 \mathrm{a}$ & 0.00 & $26.04 \mathrm{a}$ \\
\hline $50{ }^{\circ} \mathrm{C}$ & $16.74 \mathrm{a}$ & $22.90 \mathrm{~b}$ & $54.28 \mathrm{a}$ & $0.15 \mathrm{a}$ & 0.00 & $22.88 \mathrm{a}$ \\
\hline $60{ }^{\circ} \mathrm{C}$ & $13.17 \mathrm{~b}$ & $33.28 \mathrm{a}$ & $59.53 \mathrm{a}$ & $0.13 \mathrm{a}$ & 0.00 & $20.56 \mathrm{~b}$ \\
\hline $70^{\circ} \mathrm{C}$ & $3.04 \mathrm{c}$ & $35.95 \mathrm{a}$ & $41.91 \mathrm{~b}$ & $0.14 \mathrm{a}$ & 0.00 & $21.48 \mathrm{a}$ \\
\hline $\mathrm{F}$ test & $268.14 * *$ & $88.61 * *$ & $13.90 * *$ & $1.24 * *$ & 0.00 & $5.26 * *$ \\
\hline \multicolumn{7}{|l|}{ Time (days) } \\
\hline 0 & $6.94 \mathrm{e}$ & $11.63 \mathrm{~d}$ & $60.29 \mathrm{a}$ & $0.31 \mathrm{a}$ & 0.00 & $19.84 \mathrm{~b}$ \\
\hline 30 & $9.77 \mathrm{~d}$ & $26.09 \mathrm{c}$ & $53.36 \mathrm{a}$ & $0.11 \mathrm{~b}$ & 0.00 & $24.53 \mathrm{a}$ \\
\hline 60 & $13.00 \mathrm{~b}$ & $39.08 \mathrm{a}$ & $56.03 \mathrm{a}$ & $0.11 \mathrm{~b}$ & 0.00 & $27.93 \mathrm{a}$ \\
\hline 90 & $11.66 \mathrm{c}$ & $32.43 \mathrm{~b}$ & $42.50 \mathrm{~b}$ & $0.08 \mathrm{~b}$ & 0.00 & $24.21 \mathrm{a}$ \\
\hline 120 & $15.60 \mathrm{a}$ & $26.98 \mathrm{c}$ & $55.87 \mathrm{a}$ & $0.10 \mathrm{~b}$ & 0.00 & $17.18 \mathrm{~b}$ \\
\hline F-test & $67.66 * *$ & $147.23 * *$ & $8.04 * *$ & $86.89 * *$ & 0.00 & $12.38 * *$ \\
\hline Treatment $\times$ time & $10.75 * *$ & $26.81 * *$ & $7.22 * *$ & $3.01 * *$ & 0.00 & $4.19 * *$ \\
\hline CV $(\%)$ & 0.37 & 0.29 & 0.13 & 0.36 & 0.00 & 0.14 \\
\hline
\end{tabular}

Means followed by the same lowercase letter in the columns do not differ from each other according to Tukey's test ( $\mathrm{P}<0.01)$.

Oil acidity remained elevated at the other drying temperatures $\left(40,50\right.$ and $\left.60{ }^{\circ} \mathrm{C}\right)$ throughout the storage period (Tables 3 and 4), except for $70{ }^{\circ} \mathrm{C}$, in which case it remained low. According to Pohndorf (2012), increased oil acidity indices result from the hydrolytic rancidity process, which might or might not have occurred by an enzymatic action, considering that the decomposition of glycerides is accelerated with exposure to light. Thus, the temperature of $70{ }^{\circ} \mathrm{C}$ inhibited alterations in the pulp due to the shorter fruit storage time until the desired moisture was achieved. Increasing acidity indices in the pulp oil were also reported by Queiroz (2016) during the storage of macaúba fruit for up to 30 days, after they were subjected to different harvest/cleaning methods, followed by oven-drying at $60^{\circ} \mathrm{C}$ for $24 \mathrm{~h}$ (or no drying). 
Results pertaining to the peroxide index in the pulp oil from the dried fruits (Table 5) indicated that exposure to heat significantly influenced the degree of oxidization, which was highest at the temperatures of 60 and $70{ }^{\circ} \mathrm{C}$. Overall, storage time contributed to the increase in peroxide index (Tables 5 and 6). The fruit pulps provided an oil that met the standards of quality for this index as established by Anvisa $\left(20 \mathrm{mEq} \mathrm{kg}{ }^{-1}\right)\left(\mathrm{RDC} \mathrm{n}^{\circ} 270\right.$ of September 22, 2005) for virgin palm oil when the material is dried at the temperatures of 40 to $50^{\circ} \mathrm{C}$ (0 days). This suggests that, after drying, the storage conditions did not prevent oxidization, which was potentiated by the increase in drying temperature.

Table 6.

Chances in acidity, peroxide and iodine indices of pulp and nut oil from macaúba fruits dried in different air conditions and stored for up to 120 days

\begin{tabular}{|c|c|c|c|c|c|}
\hline \multirow{2}{*}{ Treatment } & \multicolumn{5}{|c|}{ Storage time (days) } \\
\hline & 0 & 30 & 60 & 90 & 120 \\
\hline \multicolumn{6}{|c|}{ Acidity index of pulp oil $\left(\mathrm{mg} \mathrm{NaOH} \mathrm{g}^{-1}\right)$} \\
\hline $40^{\circ} \mathrm{C}$ & $8.50 \mathrm{Ca}$ & $11.87 \mathrm{Ba}$ & $11.35 \mathrm{Bb}$ & $12.86 \mathrm{Ba}$ & $18.56 \mathrm{Ab}$ \\
\hline $50^{\circ} \mathrm{C}$ & $8.71 \mathrm{Ca}$ & $13.26 \mathrm{Ba}$ & $21.71 \mathrm{Aa}$ & $15.93 \mathrm{Ba}$ & $24.09 \mathrm{Aa}$ \\
\hline $60{ }^{\circ} \mathrm{C}$ & $8.12 \mathrm{Ba}$ & $11.84 \mathrm{Aa}$ & $15.40 \mathrm{Ab}$ & $14.92 \mathrm{Aa}$ & $15.56 \mathrm{Ab}$ \\
\hline $70^{\circ} \mathrm{C}$ & $2.44 \mathrm{Ab}$ & $2.10 \mathrm{Ab}$ & $3.53 \mathrm{Ac}$ & $2.95 \mathrm{Ab}$ & $4.20 \mathrm{Ac}$ \\
\hline \multicolumn{6}{|c|}{ Peroxide index of pulp oil $\left(\mathrm{mEq} \mathrm{kg}^{-1}\right)$} \\
\hline $40^{\circ} \mathrm{C}$ & $4.94 \mathrm{Bb}$ & $20.49 \mathrm{Ab}$ & $20.16 \mathrm{Ab}$ & $23.32 \mathrm{Ab}$ & $15.25 \mathrm{Ab}$ \\
\hline $50{ }^{\circ} \mathrm{C}$ & $5.32 \mathrm{Cb}$ & $25.97 \mathrm{Ba}$ & $41.91 \mathrm{Aa}$ & $21.46 \mathrm{Bb}$ & $19.85 \mathrm{Bb}$ \\
\hline $60{ }^{\circ} \mathrm{C}$ & $17.44 \mathrm{Ca}$ & $24.26 \mathrm{Ba}$ & $51.16 \mathrm{Aa}$ & $43.56 \mathrm{Aa}$ & $29.99 \mathrm{Bb}$ \\
\hline $70^{\circ} \mathrm{C}$ & $18.80 \mathrm{Aa}$ & $33.65 \mathrm{Aa}$ & $43.10 \mathrm{Aa}$ & $41.37 \mathrm{Aa}$ & $42.81 \mathrm{Aa}$ \\
\hline \multicolumn{6}{|c|}{ Iodine index of pulp oil } \\
\hline $40{ }^{\circ} \mathrm{C}$ & $61.72 \mathrm{Aa}$ & $66.42 \mathrm{Aa}$ & $60.98 \mathrm{Aa}$ & $60.30 \mathrm{Aa}$ & $52.17 \mathrm{Aa}$ \\
\hline $50{ }^{\circ} \mathrm{C}$ & $63.19 \mathrm{Aa}$ & $62.96 \mathrm{Aa}$ & $57.29 \mathrm{Aa}$ & $35.96 \mathrm{Aa}$ & $51.98 \mathrm{Aa}$ \\
\hline $60{ }^{\circ} \mathrm{C}$ & $59.70 \mathrm{Aa}$ & $69.33 \mathrm{Aa}$ & $72.28 \mathrm{Aa}$ & $33.76 \mathrm{Aa}$ & $62.59 \mathrm{Aa}$ \\
\hline $70^{\circ} \mathrm{C}$ & $64.57 \mathrm{Aa}$ & $14.71 \mathrm{Bb}$ & $33.55 \mathrm{Ba}$ & $39.96 \mathrm{Aa}$ & $56.75 \mathrm{Aa}$ \\
\hline \multicolumn{6}{|c|}{ Acidity index of nut oil $\left(\mathrm{mg} \mathrm{NaOH} \mathrm{g}^{-1}\right)$} \\
\hline $40{ }^{\circ} \mathrm{C}$ & $0.35 \mathrm{Aa}$ & $0.09 \mathrm{Ba}$ & $0.14 \mathrm{Ba}$ & $0.07 \mathrm{Ba}$ & $0.07 \mathrm{Ba}$ \\
\hline $50{ }^{\circ} \mathrm{C}$ & $0.26 \mathrm{Aa}$ & $0.17 \mathrm{Ba}$ & $0.09 \mathrm{Ba}$ & $0.08 \mathrm{Ba}$ & $0.16 \mathrm{Ba}$ \\
\hline $60{ }^{\circ} \mathrm{C}$ & $0.31 \mathrm{Aa}$ & $0.08 \mathrm{Ba}$ & $0.08 \mathrm{Ba}$ & $0.08 \mathrm{Ba}$ & $0.08 \mathrm{Ba}$ \\
\hline $70^{\circ} \mathrm{C}$ & $0.33 \mathrm{Aa}$ & $0.08 \mathrm{Ba}$ & $0.14 \mathrm{Ba}$ & $0.08 \mathrm{Ba}$ & $0.08 \mathrm{Ba}$ \\
\hline \multicolumn{6}{|c|}{ Iodine index of nut oil $\left(\mathrm{g} \mathrm{I}_{2} 100 \mathrm{~g}^{-1}\right)$} \\
\hline $40^{\circ} \mathrm{C}$ & $23.05 \mathrm{Aa}$ & $27.73 \mathrm{Aa}$ & $29.35 \mathrm{Aa}$ & $26.48 \mathrm{Aa}$ & $23.58 \mathrm{Aa}$ \\
\hline $50^{\circ} \mathrm{C}$ & $12.18 \mathrm{Aa}$ & $21.00 \mathrm{Aa}$ & $36.12 \mathrm{Aa}$ & $22.76 \mathrm{Aa}$ & $22.36 \mathrm{Aa}$ \\
\hline $60{ }^{\circ} \mathrm{C}$ & $21.20 \mathrm{Aa}$ & $25.00 \mathrm{Aa}$ & $23.90 \mathrm{Aa}$ & $21.03 \mathrm{Aa}$ & $11.65 \mathrm{Aa}$ \\
\hline $70^{\circ} \mathrm{C}$ & $22.94 \mathrm{Aa}$ & $24.39 \mathrm{Aa}$ & $22.36 \mathrm{Aa}$ & $26.58 \mathrm{Aa}$ & $11.14 \mathrm{Aa}$ \\
\hline
\end{tabular}

Means followed by the same lowercase letter in the columns and uppercase letter in the row do not differ from each other according to Tukey's test $(\mathrm{P}<0.01)$. 
Exposure to heat interfered with the degradation reactions, considering that the fresh pulp, which was not dried artificially, exhibited lower acidity and peroxide indices in its oil $\left(5.31 \mathrm{mg} \mathrm{NaOH} \mathrm{g}^{-1}\right.$ and $3.73 \mathrm{mEq} \mathrm{kg}^{-1}$, respectively).

The dried macaúba pulp oil showed a high iodine index, indicating a high number of unsaturated double bonds. The pulp oil from the fruit dried at 70 ${ }^{\circ} \mathrm{C}$ showed a lower iodine index compared to those from fruits dried at the other temperatures, which did not differ from each other. Over the storage period, this index was lowest at 90 days of storage (Tables 5 and 6). The obtained iodine values were close to the $49.93 \mathrm{~g} \mathrm{I}_{2} 100 \mathrm{~g}^{-1}$ found in guariroba oil (Syagrus oleracea) by Nozaki et al. (2012).

No significant difference was detected between the fruits dried at different temperatures for the lipid

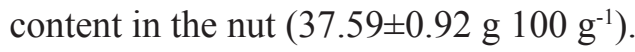

The nut oil acidity indices (Tables 4 and 5) differed statistically after the fruits were dried at different temperatures. Oliveira, Neves and Silva (2013) reported acidity values higher than those obtained in this study, in crude babassu (Attalea speciosa) oil (2.22 to $\left.5.91 \mathrm{mg} \mathrm{NaOH} \mathrm{g}^{-1}\right)$.

The peroxide index was not detected in the macaúba nut oil after the fruits were dried or during the storage period F. A. Silva et al. (2011) found peroxide indices of 2.32 to $2.57 \mathrm{mEq} \mathrm{kg}^{-1}$ in macadamia nut.

Therefore, the acidity and peroxide indices in the nut were lower than the minimum of $(<4 \mathrm{mg} \mathrm{KOH}$ $\mathrm{g}^{-1}$ and $<15 \mathrm{mEq} \mathrm{kg}^{-1}$, respectively) established for crude oils (RDC n ${ }^{\circ} 270$ of September 22, 2005) until the end of the storage period.

Dried-macaúba nut oil showed a lower iodine index than the pulp oil, indicating a lower number of unsaturated double bonds. The obtained values were higher than the $7.34 \mathrm{~g} \mathrm{I}_{2} 100 \mathrm{~g}^{-1}$ found in macaúba nut oil by Nozaki et al. (2012).

These results demonstrate that, irrespective of temperature and storage time, drying did not significantly influence the quality of macaúba nut oil possibly due to the predominance of saturated fatty acids in the nut and protection against heat transference provided by the endocarp to the seed.

\section{Conclusions}

Drying and storage time reduce the ascorbic acid and carotenoid contents of fruit pulp. Lower temperatures provide pulps with a higher freeradical sequestering ability. Pulp oil quality was compromised by drying and storage. Newly harvested macaúba fruits can be dried at 40, 50, 60 or $70{ }^{\circ} \mathrm{C}$ and stored for up to 120 days without compromising nut oil quality.

\section{Acknowledgments}

The authors thank the Center for Food Technology and Public Health (UTASP), the Physics-Chemistry Laboratory (LAFQ), the Health and Development Program in the Central-West Region and the Federal University of Mato Grosso do Sul.

\section{References}

Amaral, F. P., Broetto, F., Batistella, C. B., \& Jorge, S. M. A. (2011). Extração e caracterização qualitativa do óleo da polpa e amêndoas de frutos de macaúba [acrocomia aculeata (jacq) lodd. ex mart] coletada na região de Botucatu. Revista Energia na Agricultura, 26 (1), 12-20. doi: 10.17224/ EnergAgric.2011v26n1p12-20

Amaral, I. A., Loubet, P. S., Fo , Cavalheiro, L. F., Galvani, F., \& Santos, E. F. (2019). Comparação das propriedades químicas e do perfil lipídico das farinhas de bocaiuva (Acrocomia spp.) despolpada de forma manual e mecânica. Revista de Agricultura Neotropical, 6 (2), 59-63. doi: 10.32404/rean. v6i2.2737

Ball, E. (2013). Recomendações para projeto de unidades de beneficiamento e armazenagem de grãos com enfoque em segurança do trabalho. Monografia do trabalho de conclusão de curso de especialização, Universidade Regional do Noroeste do Estado do Rio Grande do Sul, Ijuí, RS, Brasil. 
RDC $n^{\circ}$ 270, de 22 de setembro de 2005. Aprova o Regulamento técnico para óleos vegetais, gorduras vegetais e creme vegetal. Recuperado em http:// portal.anvisa.gov.br/documents/10181/2718376/ RDC_270_2005_.pdf/8f80bf4d-a38a-4699-9f8f$582186 \mathrm{~b} 37 \overline{9} \mathrm{~d}$

RDC no 263, de 22 de setembro de 2005 de 2005. Regulamento técnico para produtos de cereais, amidos, farinhas e farelos. Recuperado em http:// bvsms.saude.gov.br/bvs/saudelegis/anvisa/2005/rdc 0263_22_09_2005.html

Chitarra, M. I. F., \& Chitarra, A. B. (2005). Pós-colheita de frutos e hortaliças: fisiologia e manuseio. Lavras: Ed UFLA.

Chuba-Machado, C. A. (2018). Construção e avaliação de um protótipo para despolpar frutos de Acrocomia $s p$.. Tese de doutorado, Universidade Federal da Grande Dourados, Dourados, MS, Brasil.

Coimbra, M. C., \& Jorge, N. (2011). Proximate composition of guariroba (Syagrus oleracea), jerivá (Syagrus romanzoffiana) and macaúba (Acrocomia aculeata) palm fruits. Food Research International, 44(7), 2139-2142. doi: 10.1016/j. foodres.2011.03.032

Ferreira, A. N., Santos, C. P. A. dos, Costa, G. L. de A., \& Gebara, K. S. (2013). Utilização do extrato de bocaiúva (acrocomia aculeata) como um alimento funcional do tipo "shake". Interbio, 7(1), 61-71. Recuperado em https://www.unigran.br/dourados/ interbio/paginas/ed_anteriores/index.php?id=artigo $\&$ codigo $=\% 2088 \&$ cam $=$ vol 7 num 1

Ferreira Neto, C. J. F., Figueirêdo, R. M. \& Queiroz, A. J. M. (2005). Avaliação sensorial e da atividade de água em farinhas de mandioca temperadas. Ciência e Agrotecnologia, 29(4), 795-802. doi: 10.1590/ S1413-70542005000400011

Fisk II, P. S. (2011). Few favorable associations between fruit and vegetable intake and biomarkers for chronic disease risk in American adults. Nutrition Research, 31(8), 616-624. doi: 10.1016/j.nutres.2011.07.005

Fukumoto, L. R., \& Mazza, G. (2000). Assessing antioxidant and prooxidant activities of phenolic compounds. Journal of Agricultural and Food Chemistry, 48(8), 3597-3604. doi: 10.1021/ jf000220w

Gonçalves, M. G. (2018). Secagem de frutos de macaúba em função da temperatura do ar. Dissertação de mestrado, Universidade Federal de Viçosa, MG, Brasil.
Instituto Adolfo Lutz. (2008). Métodos físico-químicos para análise de alimentos. São Paulo: IAL.

Kopper, A. C., Saravia, A. P. K., Ribani, R. H. \& Lorenzi, G. M. A. C. (2009). Utilização tecnológica da farinha de bocaiuva na elaboração de biscoito tipo cookie. Alimentos \& Nutrição, 20(3), 463469. Recuperado em https://www.researchgate.net/ publication/49600180_Utilizacao_tecnologica_da farinha_de_bocaiuva_na_elaboracao_de_biscoitos_ tipo_cookie

Leitman, P., Soares, K., Henderson, A., Noblick, L., \& Martins, R. C. (2018). Arecaceae in lista de espécies da flora do Brasil. [S.1.] : [s.n]. Recuperado em http:// floradobrasil.jbrj.gov.br/jabot/floradobrasil/FB53

Luzia, D. M. M., \& Jorge, N. (2010). Potencial antioxidante de extratos de sementes de limão (Citrus limon). Ciência e Tecnologia de Alimentos, 30(2), 489-493. doi: 10.1590/S0101-20612010000200029

Munhoz, C. L., Guimarães, R. C. A., Nozaki, V., SanjinezArgandoña, E. J. U., \& Macedo, M. L. R. (2018). Composição química e de fatores antinutricionais de frutos de bocaiuva. Revista Ambiência, 14(1), 212224. doi: 10.5935/ambiencia.2018.15.01

Nozaki, V. T., Munhoz, C. L., Guimarães, R. C. A., Hiane, P. A., Andreu, M. P., Viana, L. H., \& Macedo, M. L. R. (2012). Perfil lipídico da polpa e amêndoa da guarirova. Ciência Rural, 42(8), 1518-1523. doi: $10.1590 / \mathrm{S} 0103-84782012000800030$

Oliveira, F. F. (2016). Sistemas nanoestruturados contendo óleos de polpa e de amêndoa de Acrocomia aculeata (Jacq.) Lodd.: preparação e caracterização físico-química. Tese de doutorado, Universidade de São Paulo, SP, Brasil.

Oliveira, R. S., Neves, J. A., \& Silva, M. J. M. da. (2013). Avaliação da qualidade físico-química do óleo bruto da amêndoa de babaçu (Orbignya spp). Comunicata Scientiae, 4(2), 161-167. Recuperado em https:// www-periodicos-capes-gov-br.ez51.periodicos. capes.gov.br/index.php?option $=$ com_pmetabusca pYnJhcnkvbGlid2ViL2FjdGlvbi9zZWFyY2guZG8/ dmlkPUNBUEVTX1Yx\&Itemid=124

Pinto, J., \& Neves, R. (2010). HACCP: análise de riscos no processamento alimentar. (2a ed.). Porto: Publindústria.

Pohndorf, R. S. (2012). Efeitos da umidade e do resfriamento no armazenamento sobre a qualidade de grãos e do óleo de soja para fins comestiveis e de produção de biodiesel. Dissertação de mestrado, Universidade Federal do Paraná, Pelotas, RS, Brasil. 
Queiroz, L. A. N. (2016). Análise de procedimentos póscolheita do fruto da macaúba (Acrocomia aculeata) e refino do óleo da polpa. Tese de doutorado, Universidade Federal de Minas Gerais, Belo Horizonte, MG, Brasil.

Reis, D. S., Figueiredo, A. Neto, Ferraz, A. V.. \& Freitas, S. T. (2017). Produção e estabilidade de conservação de farinha de acerola desidratada em diferentes temperaturas. Brazilian Journal of Food Technology, 20(1), 1-7. doi: 10.1590/1981-6723.8315

Rios, A. O., Antunes, L. M. G., \& Bianchi, M. L. P. (2009). Proteção de carotenoides contra radicais livres gerados no tratamento de câncer com cisplatina. Revista Alimentos e Nutrição, 20(2), 342350. Recuperado em https://www.researchgate.net/ publication/49600165_Protecao_de_carotenoides_ contra_radicais_livres_gerados_no_tratamento_de cancer_com_cisplatina

Rodriguez-Amaya, D. B. (2001). A guide to carotenoid analysis in foods. Washington: Internacional Life Sciences Institute Press.

Roesler, R., Malta, L. G., Carrasco, L. C., Holanda, R. B., Souza, C. A. S., \& Pastore, G. M. (2007). Atividade antioxidante de frutas do cerrado. Ciência $e$ Tecnologia de Alimentos, 27(1), 53-60. doi: 10.1590/ S0101-20612007000100010

Sanjinez-Argandoña, E. J., \& Chuba, C. A. M. (2011). Caracterização biométrica, física e química de frutos da palmeira bocaiuva. Acrocomia aculeata (Jacq) Lodd. Revista Brasileira de Fruticultura, 33(3), 10231028. doi: 10.1590/S0100-29452011000300040
Silva, F. A., Gonçalves, L. A. G., Damiani, C., Gonçalves, M. A. B., Soares Junior, M. S., \& Marsaioli Junior, A. (2011). Estabilidade oxidativa de amêndoas de noz macadâmia secas por micro-ondas com ar quente. Pesquisa Agropecuária Tropical, 41(2), 286292. doi: 10.5216/pat.v41i2.9961

Silva, P. B. da, Ramiro, M. M., Iriguchi, E. K. K., Corrêa, W. A., Lowe, J., Cardoso, C. A. L., Arena, A. C., Muzzi, R. M. (2019). Antidiabetic, cytotoxic and antioxidant activities of oil extracted from Acrocomia aculeata pulp. Natural Product Research, 33(16), 2413-2416. doi: 10.1080/14786419.2018.1446006

Silva, P. H. (2017). Caracterização de acrocomia aculeata e acrocomia totai por meio de descritores agromorfológicos. Dissertação de mestrado, Instituto Agronômico, Campinas, SP, Brasil.

Silva, V. M., Marinho, E. R. A., Guimarães, R. C. A., Campos, R. P., Borsato, A. V., Donadon, J. R. (2017). Protocolo para determinação de umidade em frutos de bocaiuva. Anais do Simpósio de Frutos Nativos e Exóticos. Universidade Federal de Mato Grosso do Sul, Campo Grande, MS, Brasil.

Silva, V. M., Campos, R. P., Borsato, A. V., Candido, C. J., \& Donadon, J. R. (2018) Bocaiuva jelly: preparation, physicochemical and sensory evaluation. Revista Brasileira de Fruticultura, 40(5), 1-9. doi: 10.1590/0100-29452018846

Souza, R. S., Cueller, J. P., Donadon, J. R., Guimarães, R, C. A. (2019). Compostos bioativos em geleia de bocaiuva com maracujá. Multitemas, 24(57), p. 7994. doi: http://dx.doi.org/10.20435/multi.v0i.1803 